\title{
Mortar Produced with Sulphur Slime Aggregate
}

\section{Vytautas Bocullo, Danutė Vaičiukynienė*, Gitana Šukaitytė}

Kaunas University of Technology, Faculty of Civil Engineering and Architecture Studentu st. 48, LT-51367 Kaunas, Lithuania

\section{Aras Kantautas}

Kaunas University of Technology, Faculty of Chemical Technology Radvilènu rd. 19, Kaunas 5025

\section{Ruben P. Borg}

Faculty for the Built Environment, Built Environment Building

Room 213, University of Malta, Msida, MSD 2080, Malta

*Corresponding author: danute.palubinskaite@ktu.lt

\section{$\Gamma$} crossef http://dx.doi.org/10.5755/j01.sace.19.2.17635
It is known that the use of various industrial wastes as recycled aggregate for concrete to build environmentally sustainable structures has several practical and economic advantages. Usually such recycled aggregates consist mainly of crushed concrete and crushed asphalt pavement material. However, in this study a by-product of acid - sulphur slime is used as a partial substitute for natural fine aggregate (sand). Sulphur slime is a solid material consisting mainly of elemental orthorhombic sulphur with some impurities like gypsum and anhydrite. The goal of this research is to investigate whether it is possible to manufacture concrete with sulphur slime despite the presence of elemental sulphur. Each set of samples analyzed was based on 5 different compositions with $0 \%, 10 \%, 20 \%, 30 \%, 40 \%$ Sulphur slime as a substitute of aggregate. Samples was tested for their mechanical characteristics including the compressive and flexural strength. The samples structure was analyzed with SEM and optical microscopy and the composition of the materials was analyzed through SEM and XRD. The inclusion of Sulphur slime led to a reduction in the mechanical properties of the material, related to the formation of secondary ettringite mineral and associated expansion within the material.

Keywords: sulphur, aggregate, mortar, recycled aggregate, industrial waste.

Concrete has been widely used as a construction material due to its versatility. Concrete as an artificial stone, is based on a mixture of binding materials (cement), aggregate (sand, gravel) and water. Natural sand is becoming scarcer and costlier due to its non-availability. The use of industrial waste as construction material for environmentally sustainable structures has several practical and economic advantages. According to Li et al. ( 2015), a waste-rubber-modified recycled-aggregate concrete intended for road construction was produced by adding granulated waste rubber to recycled-aggregate concrete. Test results show that this concrete exhibits an enhanced strain rate effect and has good impact resistance relative to recycled-aggregate concrete. In the research conducted by Senin etc al. (Senin et al., 2016), the chemical and physical properties of tyre rubber ash and the natural sand have been analysed. Tyre rubber ash performed in a better way than natural sand due to its chemical composition, containing sulphur trioxide and zinc oxide. Rubber ash seems to be a suitable material to use in concrete as sand replacement. Singh et al. (2015) investigated the effect of granite dust on the rheological, mechanical and durability prop-

\section{Introduction}

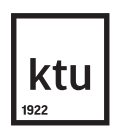

Journal of Sustainable Architecture and Civil Engineering Vol. 2 / No. 19 / 2017 pp. 49-56

DOI 10.5755/j01.sace.19.2.17635 (c) Kaunas University of Technology 
erties of concrete. The authors state that test results show huge potential for granite dust as a replacement of natural fine aggregate. Aslam et al. (2015) stated that it is possible to produce environmentally-friendly and high strength structural lightweight aggregate concrete by incorporating high volume waste lightweight aggregate from the palm oil industry. De Brito et al. (De Brito et al. 2016) investigated the feasibility of incorporating high-quality recycled concrete aggregates in new concrete, providing a recycling option for precast rejects. These recycled aggregates had negligible effects on concrete properties and structural performance. In research conducted by Medina et al. (Medina et al., 2016), 20\% and 25\% of the natural coarse aggregate in concrete was replaced with recycled aggregate from the sanitary ware industry. The relationships between the durability indicators are not modified in the new concretes. The chloride penetration was slightly deeper in recycled concretes. The electrical resistivity was higher in the recycled concretes when compared to the control reference concrete. The recycled concrete would exhibits satisfactory durability throughout its service life.

There are several studies referring to the use of sulphur in Portland cement concrete. Lee et al. (regardless of the water-cement ratio (W/C2014) proposes a mix design for concrete having modified sulphur-coated aggregate to enhance the durability of Portland cement concrete. Melted-modified sulphur was mixed with aggregate to coat the aggregate surface at a speed of $20 \mathrm{rpm}$ for $120 \mathrm{~s}$. The modified sulphur-coated aggregate considerably improved resistance to sulphuric acid attack and freezing-thaw action. The coated modified sulphur aggregate at a 5\% dosage consequently led to good results with respect to the mechanical properties and durability of MSCA concrete. Thomas et al. (2013) presented a characterization program for recycled aggregate containing sulphur and recycled concrete. The authors concluded that the use of recycled aggregate concrete, with or without sulphur, is viable for the manufacture of recycled structural concretes for applications without exposure to high temperatures. However, the use of the fine fraction means a significant loss in material properties.

Książek states that polymerized sulphur is suitable to seal concrete, including cracks in concrete, against the ingress of water and contaminants, addressing the standard requirements of waterproof concrete. This paper presents the results of the experimental investigation for cement concrete impregnated with polymerized sulphur, applied as the industrial waste material.

The present research the application of sulphur slime as concrete fine aggregate (sand) was investigated. The sulphur slime is a by-product of sulphuric acid $\left(\mathrm{H}_{2} \mathrm{SO}_{4}\right)$ production waste from fertilizer plants. The slime results from the cleaning of sulphur filters in smelters, collectors, and the sulphur repository. The amount of slime formed is calculated according to the norm (1t of $\mathrm{H}_{2} \mathrm{SO}_{4}-0.45 \mathrm{t}$ of slime). The aim of this work is to determine the main properties of Portland cement mortar produced by replacing part of the natural fine aggregate with sulphur slime.

\section{Experimental Investigation}

The XRD analysis for raw materials were performed on the D8 Advance diffractometer (Bruker AXS) operating at a tube voltage of $40 \mathrm{kV}$ and tube current of $40 \mathrm{~mA}$. The $X$-ray beam was filtered with a Ni $0.02 \mathrm{~mm}$ filter to select the CuKa wavelength. Diffraction patterns were recorded in a Bragg-Brentano geometry using a fast counting detector Bruker LynxEye based on silicon strip technology. The specimens were scanned over the range $2 \theta=3-60^{\circ}$ at a scanning speed of $6 \mathrm{~min}^{-1}$ using a coupled two theta/theta scan type.

The structure of hardened mortar paste was studied by the scanning electron microscope. A high resolution scanning electron microscope FEI Quanta 200 FEG with a Schottky field emission gun (FEG) was used for the research. For microscopy analysis, a "Ceti Stereo-Steddy" microscope was used. Pictures were enhanced at 50x and taken with a 21 MP digital camera.

Mortar samples were produced in accordance to the standard LST EN 196-1:2016. The samples 
were formed into $40 \times 40 \times 160 \mathrm{~mm}$ moulds and after 24 hours demoulded and cured at $20{ }^{\circ} \mathrm{C}$ in water for a period of 28 days. After 28 days' the strength of samples was tested and its micro-structure was analysed. Samples were tested for strength after 28 days using a hydraulic press. Prisms were tested for flexural strength at first through 3 point bending until breaking point and the resulting two components were tested for their compressive strength in accordance to the standard.

\section{Materials}

Portland cement CEM I 52.5 R was used as a binding material in this research. The initial setting time of Portland cement (measured with reference to standard LST EN 196-3:2007) was recorded as $110 \mathrm{~min}$, and the final setting time was recorded as $170 \mathrm{~min}$. The mineral composition of the raw materials is presented in Table 1. The fine aggregate used refers to the $0 / 4$ fraction sand which was obtained from Kvesai quarry (Lithuania).

\begin{tabular}{l|c|l|l|l|l}
\hline $\begin{array}{c}\text { Chemical } \\
\text { composition }\end{array}$ & $\begin{array}{c}\text { Portland cement } \\
\text { clinker }\end{array}$ & $\begin{array}{c}\text { Sulphur } \\
\text { slime }\end{array}$ & $\begin{array}{c}\text { Chemical } \\
\text { composition }\end{array}$ & $\begin{array}{c}\text { Portland cement } \\
\text { clinker }\end{array}$ & $\begin{array}{c}\text { Sulphur } \\
\text { slime }\end{array}$ \\
\hline $\mathrm{SiO}_{2}, \%$ & 20.54 & 3.05 & $\mathrm{CaO}$ free, $\%$ & 0.52 & - \\
\hline $\mathrm{Al}_{2} \mathrm{O}_{3}, \%$ & 5.49 & - & $\mathrm{S} \%$ & - & 55.85 \\
\hline $\mathrm{Fe}_{2} \mathrm{O}_{3}, \%$ & 3.52 & 3.34 & $3 \mathrm{CaO} \cdot \mathrm{SiO}_{2}, \%$ & 56.38 & - \\
\hline $\mathrm{CaO}, \%$ & 63.16 & 10.79 & $2 \mathrm{CaO} \cdot \mathrm{SiO}_{2}, \%$ & 16.34 & - \\
\hline $\mathrm{SO}, \%$ & 0.95 & 26.97 & $3 \mathrm{CaO} \cdot \mathrm{Al}_{2} \mathrm{O}_{3}, \%$ & 8.6 & - \\
\hline $\mathrm{Cl}, \%$ & 0.001 & - & $4 \mathrm{CaO} \cdot \mathrm{Al}_{2} \mathrm{O}_{3} \cdot \mathrm{Fe}_{2} \mathrm{O}_{3}, \%$ & 10.72 & - \\
\hline $\mathrm{MgO}, \%$ & 4.31 & - & & & \\
\hline
\end{tabular}

Table 1

Sulphur slime and Portland cement chemical composition according XRF

Sulphur slime is a grey solid material (Fig. 1a). The SEM imagine shows sulphur slime having a compact and the continuous structure of elemental sulphur, for a polymeric material. In addition, a small number of prisms - gypsum crystals are visible (Fig. 1b).

Sulphur slime (SS) used in this research was obtained from the chemical industry plant AB "Lifosa" in Lithuania. On average the plant produces $45.3 \mathrm{t}$ of SS monthly and $544 \mathrm{t}$ of SS annually. Sulphur slime consists mainly of sulphur (50\%), moisture $-3 \%$, and has a bulk density of $1.500 \mathrm{~kg} / \mathrm{m}^{3}$. Ac-
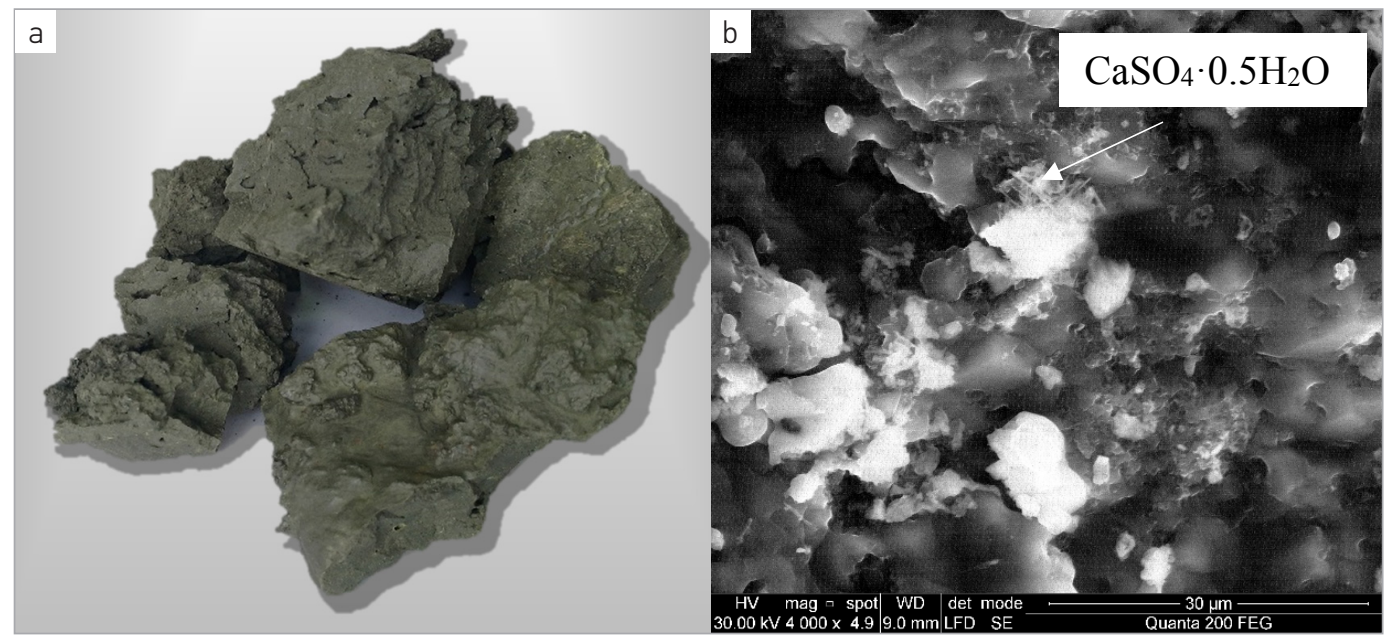

Fig. 1

Image showing lumps (diameter approx. $4-6 \mathrm{~cm}$ ) of sulphur slime (a) and SEM image of sulphur slime (b) 
cording to the XRD analysis (Fig. 2) for the mineral composition of the material, the material includes elemental sulphur and small amounts of $\mathrm{CaSO}_{4} \cdot 0.5 \mathrm{H}_{2} \mathrm{O}$ and $\mathrm{CaSO}_{4}$.

Fig. 2

XRD analysis of sulphur slime. Notes: $\mathrm{Cs}$ is semihydrate gypsum $\mathrm{CaSO}_{4} \cdot 0.5 \mathrm{H}_{2} \mathrm{O}$ $\mathrm{S}$ is elemental sulphur, $A$ is anhydrite $\mathrm{CaSO}_{4}$

\section{Table 2}

Compositions of the mortar

mixtures

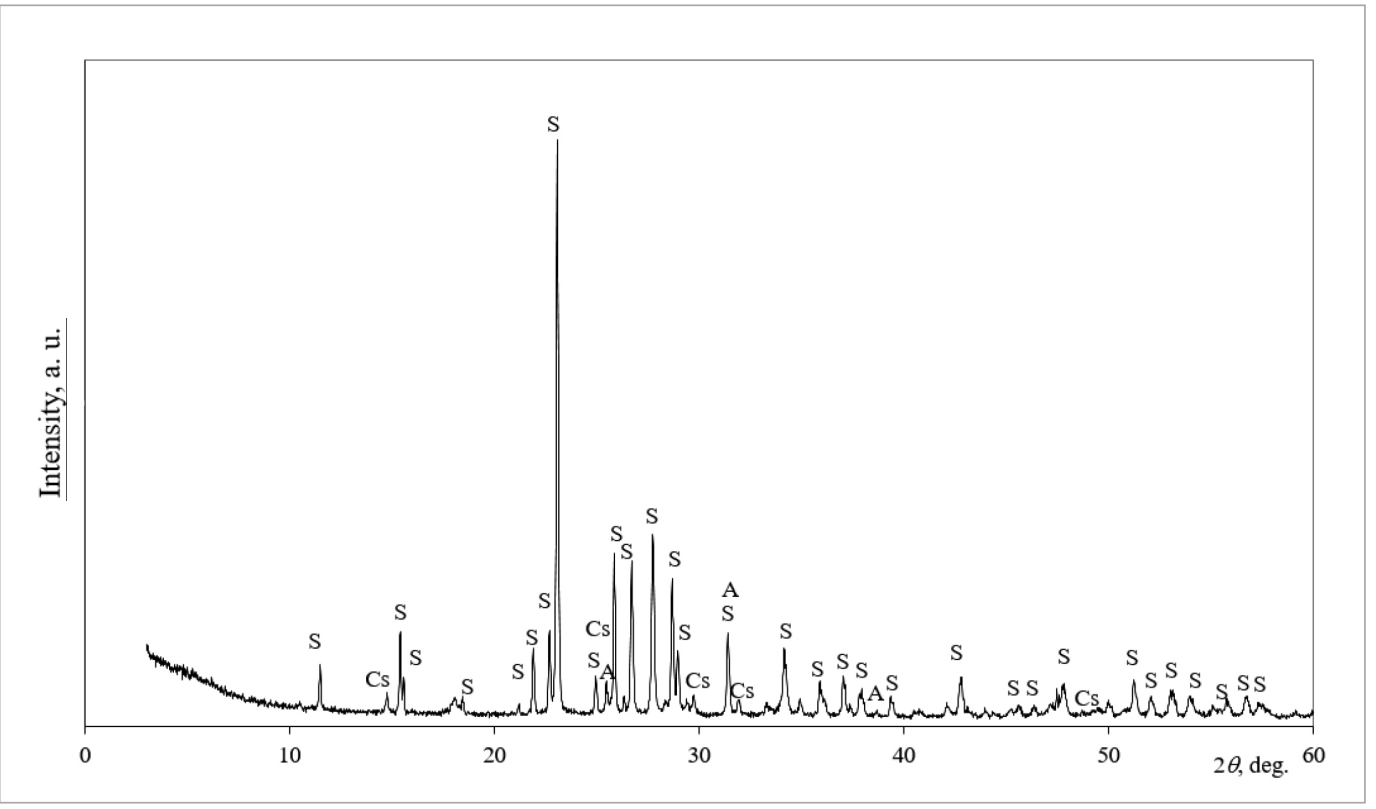

The XRF analysis shows that the larger component of the chemical composition is sulphur (55.85\%). The remaining part of sulphur is contained in $\mathrm{CaSO}_{4} \cdot 0.5 \mathrm{H}_{2} \mathrm{O}$ and $\mathrm{CaSO}_{4}$ and recalculated into $\mathrm{SO}_{3}$ making up $26.97 \%$ of the slime. In the sulphur slime there is about $10.79 \%$ of Calcium oxide and small amounts of iron and silicon oxides. (Table 1).

Blends of aggregates were prepared with crushed sulphur slime $0 / 4$ and ordinary sand 0/4. Five different mixes were prepared by changing the amount of sand mass with sulphur slime: $0 \%$ (control

\begin{tabular}{l|r|r|r|r|r}
\multicolumn{1}{c|}{ Mixtures } & Mix 1 & Mix 2 & Mix 3 & Mix 4 & Mix 5 \\
\hline Water, g & \multicolumn{5}{|c}{225} \\
\hline Portland cement, g & \multicolumn{7}{|c}{450} \\
\hline Sulphur slime, \% & 0 & 10 & 20 & 30 & 40 \\
\hline Sulphur slime, g & 0 & 135 & 270 & 405 & 540 \\
\hline Aggregate, g & 1350 & 1215 & 1080 & 945 & 810 \\
\hline
\end{tabular}
mix), 10\%, 20\%, 30\% and 40\%. The mortar mix was prepared with reference to of the standard LST EN 196-1:2016: mixing for 3 minutes, keeping $\mathrm{W} / \mathrm{C}$ ratio 0.5 and cement/aggregate ratio $1: 3$. The compositions of the mixtures are given in Table 2. The particle size distribution of aggregates is given in Fig. 3 .

Fig. 3

Graphical presentation of aggregate particle size distribution.

(a) Sand and sulphur slime,

(b) aggregates (mixtures of sand and SS)

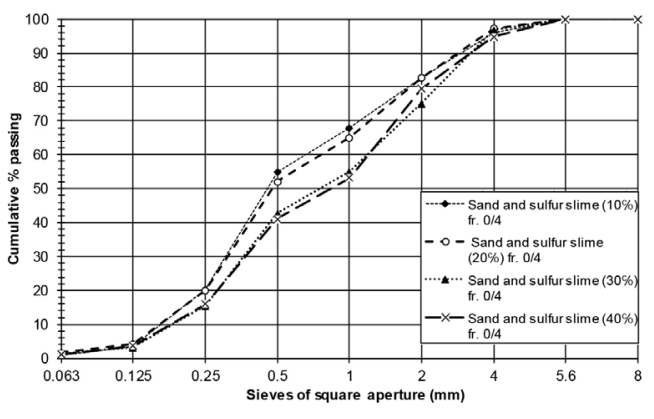

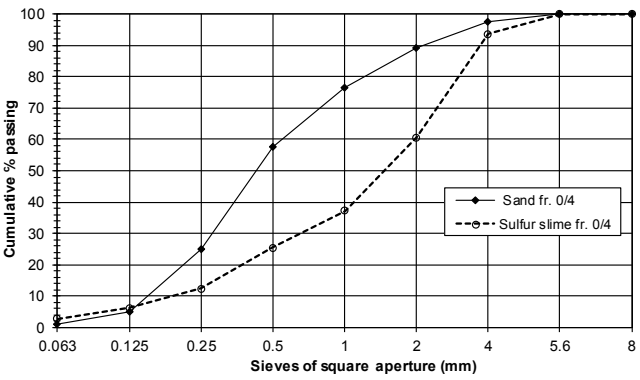

b 
Aggregates were prepared with reference to the particle size distribution-sieving method LST EN 933-1:2012. According to the sieve analysis data for aggregates it was noted that sand is finer than crushed SS (Fig. 3, a).

Initially before crushing, the SS particles were approximately $40-60 \mathrm{~mm}$ in size. The SS particles were crushed in a jaw crusher and sieved through $4 \mathrm{~mm}$ sieve. The materials used in the mortar mixtures refers to the $0 / 4$ fraction. As seen in Fig. 3 a, b $85-99 \%$ of particles are $\leq 4 \mathrm{~mm}$ so it qualifies as a $0 / 4$ fraction according to standard EN 12620.

Different types of mixtures based on different blends of sand and sulphur slime were produced. As indicated in Fig. 3, b, all types of mixtures had a similar granulometric composition. The fine aggregate mixtures became coarser, with increasing amount of SS.

The mechanical properties of mortar, including the compressive and flexural strength results are presented in Fig. 4. As seen in the figures, the samples with higher mechanical properties are those without the SS substitute. This is often the case when industrial by-products or secondary materials are used as a substitute for aggregate. Increasing the amount of sulphur

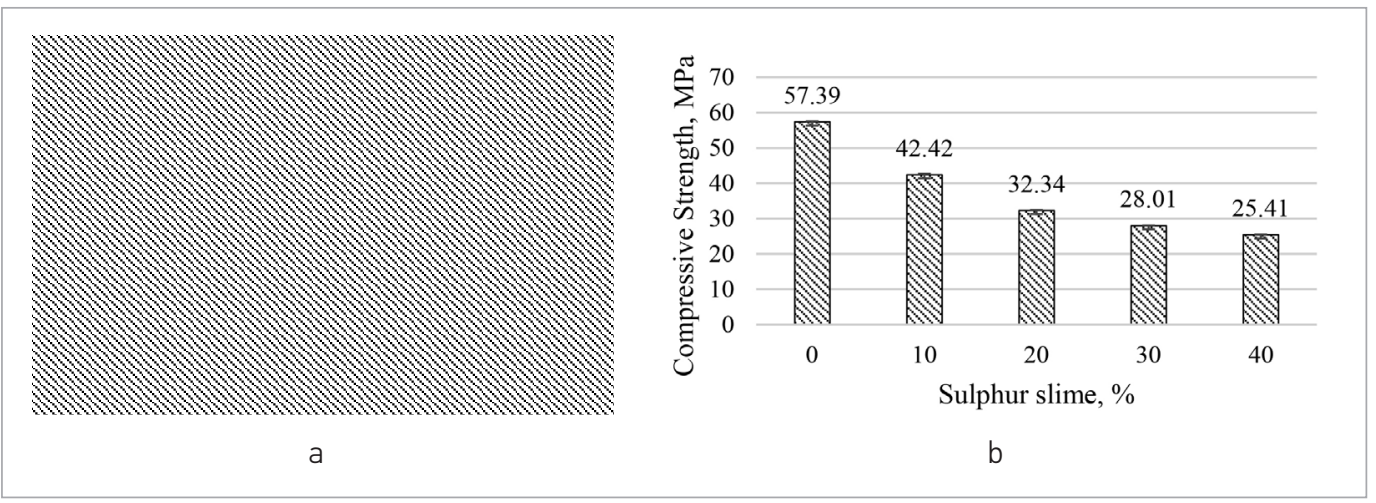

slime in the aggregate portion, gradually leads to a loss in compressive and flexural strength. Nevertheless, unlike geopolymer concrete (Vaičiukynienè et al. 2016) samples remained stable during the experiment.

The flexural test results presented in Fig. 4 a, indicate that the highest flexural strength of 7.82 $\mathrm{MPa}$ was reached without sulphur slime, and the smallest flexural strength, $3.34 \mathrm{MPa}$ was reached with $40 \%$ sulphur slime. A similar situation was noted with compression strength: the highest compressive strength of $57.39 \mathrm{MPa}$ was reached without sulphur slime while the smallest compressive strength, $-25.41 \mathrm{MPa}$ was obtained with $40 \%$ sulphur slime. Furthermore, a higher amount of SS in the mixture decreases the density (Fig. 5). Therefore, the use of fine aggregate blended with sulphur slime reduces the mechanical properties of concrete.

Following hardening, the samples with sulphur slime showed visible changes on the surface as seen in Fig. 6. Every sample with sulphur slime aggregate showed leaching of white material on the surface. Typically, samples with a higher sulphur slime content showed more leaching material on their surface.

\section{Results and discussion}

Fig. 4

The influence of SS amount on the flexural (a) and compressive (b) strength of hardened mortar

\section{Fig. 5}

The influence of the amount of SS on the density of hardened mortar 
Fig. 6a shows optical microscopy views of leached materials on the mortar sample surface. It seems that free sulphur from the aggregate leached on the surface of the samples. Leaching was observed mostly after 28 days from casting of specimen.

Fig. 6

Typical mortar samples observed using optical microscopy: view of the sample surface (a) and the $\mathrm{X}$-ray diffraction pattern of the materials, which leached on the surface (b)

Fig. 7

SEM picture of mortar with $40 \%$ sulphur slime additive

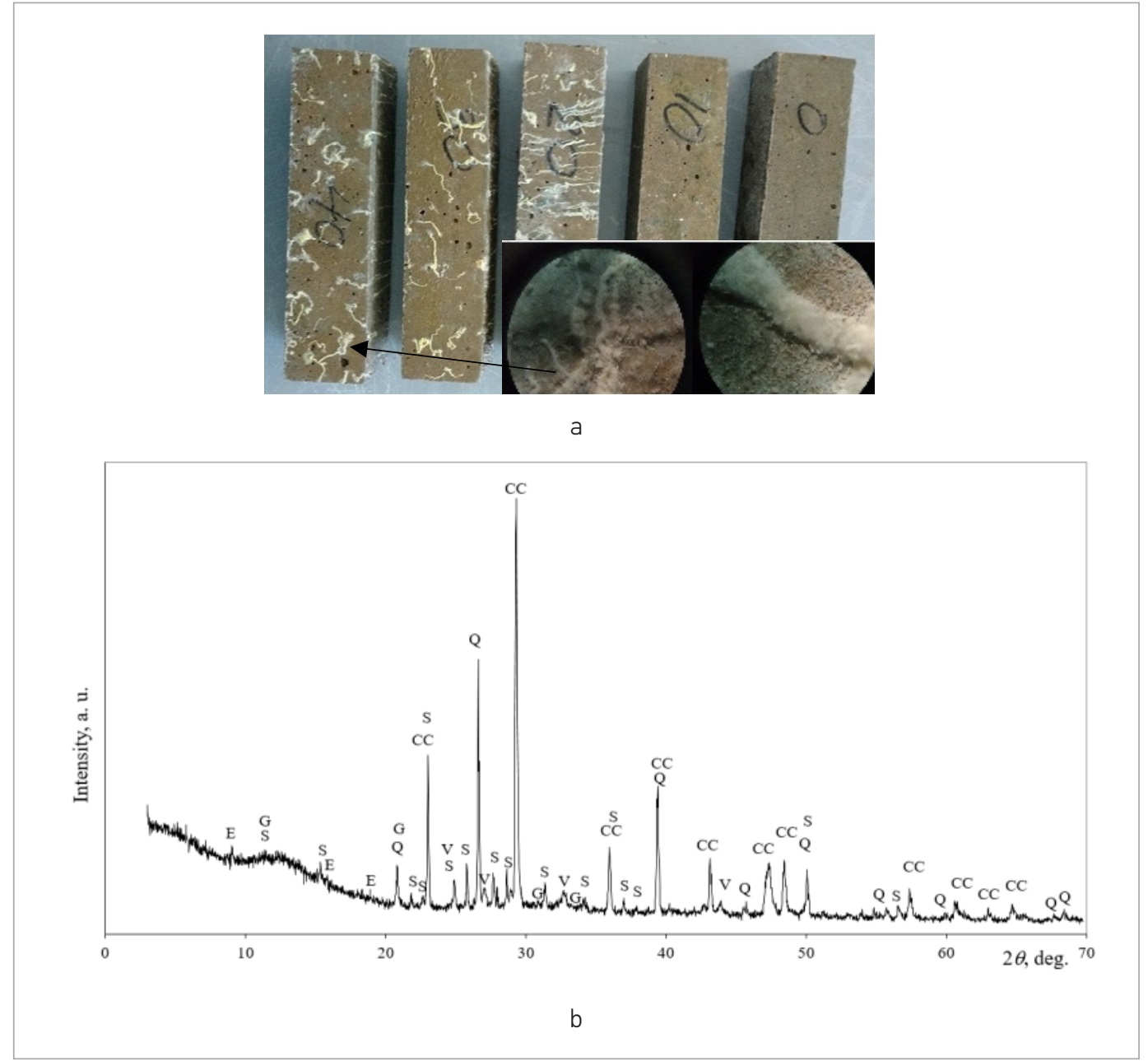

Notes: $\mathrm{E}$ - ettringite $\mathrm{Ca}_{6}\left(\mathrm{Al}\left(\mathrm{OH}_{6}\right)_{2}\left(\mathrm{SO}_{4}\right)_{3}\left(\mathrm{H}_{2} \mathrm{O}\right)_{26}\right.$ (72-646), $\mathrm{S}$ - orthorhombic sulphur, $\mathrm{S}$ (24-733), Q - quartz $\mathrm{SiO}_{2}(78$ 1252), V - vaterite $\mathrm{CaCO}_{3}(24-30), \mathrm{CC}$ - calcite $\mathrm{CaCO}_{3}$ (72-1937), $\mathrm{G}$ - gypsum $\mathrm{CaSO}_{4}\left(\mathrm{H}_{2} \mathrm{O}\right)_{2}$ (74-1905).

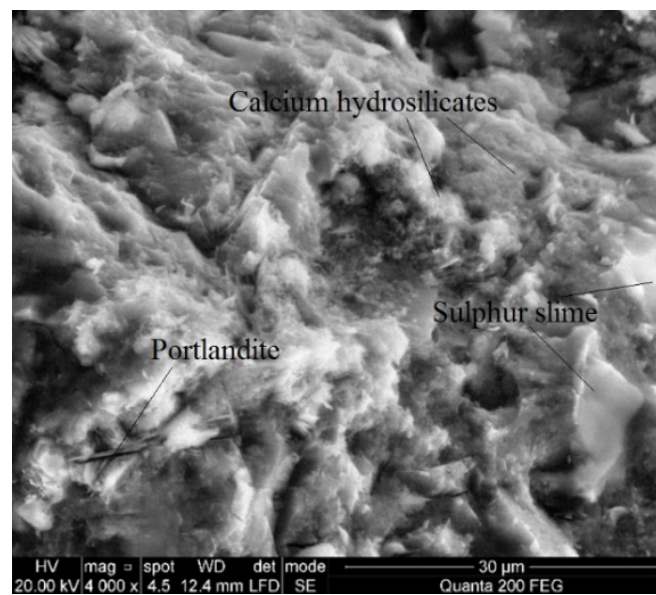

The XRD analysis of leached material was carried out. The XRD analysis indicated the presence of ettringite, which could have been produced during cement hydration, orthorhombic sulphur from sulphur slime, vaterite and calcite - products of $\mathrm{Ca}(\mathrm{OH})_{2}$ carbonation. Hydrated gypsum is probably due to the presence of sulphur slime (semihydrate gypsum hydrate) or from the Portland cement. Quartz - crystal $\mathrm{SiO}_{2}$, is a mineral normally associated with the aggregate.

The samples were analysed through Scanning Electron Microscopy. With reference to the sample with $40 \%$ sulphur slime, (Fig. 7) hex- 
agonal laminated crystals of $\mathrm{Ca}(\mathrm{OH})_{2}$ (portlandite) and elongated thin and flaky crystals of calcium hydrosilicates were noted. Some particles of sulphur slime looking like continuous structures of a polymeric material were also noted.

The reduction of compressive strength of samples can be explained through the scheme for the hydration of Portland cement (Vilkas, Vektaris, 2006). The main Portland cement hydration process is presented in the following (1):

$$
\begin{gathered}
\mathrm{C}_{3} \mathrm{~S}+\mathrm{C}_{2} \mathrm{~S}+\mathrm{C}_{3} \mathrm{~A}+\mathrm{C}_{4} \mathrm{AF}+\mathrm{CaSO}_{4} \cdot 2 \mathrm{H}_{2} \mathrm{O} \\
\stackrel{\mathrm{H}_{2} \mathrm{O}}{\longrightarrow}\left[\mathrm{nCaO} \cdot \mathrm{SiO}_{2} \cdot a q\right]+ \\
\left.+\mathrm{Ca}_{3}\left[\mathrm{Ca}_{3} \mathrm{Al}_{2}\left(\mathrm{SiO}_{3}\right)_{3}(\mathrm{OH})_{12}\right] \cdot a q\right\}+\left\{\mathrm{Ca}_{3}\left[\mathrm{Ca}_{3}(\mathrm{Al}, \mathrm{F})_{2}\left(\mathrm{SiO}_{3}\right)_{3}(\mathrm{OH})_{12}\right] \cdot a q\right\} \\
+\mathrm{C}_{3} \mathrm{~A} \cdot 3(1) \mathrm{CaSO}_{4} \cdot a q+\mathrm{C}_{3}(\mathrm{~A}, \mathrm{~F}) \cdot 3(1) \mathrm{CaSO}_{4} \cdot a q \\
+\mathrm{C}_{4} \mathrm{~A} \cdot \mathrm{aq}+\mathrm{C}_{4} \mathrm{AF} \cdot a q+\mathrm{CH}+\mathrm{mCaO}\left(\mathrm{SiO}_{2}\right)_{\text {kond }} \cdot a q
\end{gathered}
$$

$\left\{\mathrm{Ca}_{3}\left[\mathrm{Ca}_{3} \mathrm{Al}_{2}\left(\mathrm{SiO}_{3}\right)_{3}(\mathrm{OH})_{12}\right] \cdot \mathrm{aq}\right\}$ compound only occurs when clinker mineral $\mathrm{C}_{4} \mathrm{AF}$ is participating in reaction (1). This compound is resistant to sulphates. Meanwhile compound $\left\{\mathrm{Ca}_{3}\left[\mathrm{Ca}_{3} \mathrm{Al}_{2}(-\right.\right.$ $\left.\left.\mathrm{SiO}_{3}\right)_{3}(\mathrm{OH})_{12}\right]$ aqu occurs only when the clinker mineral $\mathrm{C}_{3} \mathrm{~A}$ is participating in the reaction (1). It is not resistant to sulphates and completely dissolves:

$$
\left\{\mathrm{Ca}_{3}\left[\mathrm{Ca}_{3}(\mathrm{Al}, \mathrm{Fe})_{2}\left(\mathrm{SiO}_{3}\right)_{3}(\mathrm{OH})_{12}\right] \cdot a q\right\} \stackrel{\mathrm{Ca}^{2+}, \mathrm{SO}_{4}^{2-}}{\longrightarrow} \mathrm{C}_{3} \mathrm{~A} \cdot 3 \mathrm{CaSO}_{4} \cdot a q+x \mathrm{CaO} \cdot y \mathrm{SiO}_{2} \cdot a q
$$

During 2 nd reaction, secondary ettringite forms in hardened concrete, which due to volume expansion develops internal tensions within the concrete. Furthermore, the products of 2 nd reaction do not have binding properties, so this explains why the flexural strength of samples decreased by $57 \%$ and the compressive strength decreased by $56 \%$.

In this paper, the production of mortar with part replacement of natural fine aggregate with sulphur slime was proposed. On the basis of the experiments carried out using Portland cement concrete specimens made by replacing part of natural fine aggregate with sulphur slime, a number of observations were made.

With an increasing amount of sulphur slime aggregate used as a replacement of natural sand, the flexural and compressive strength of the concrete decreased. This is because the sulphur slime aggregate can act as impurities or light-weight aggregate within the concrete. The addition of $10 \%$ crushed sulphur slime instead of natural sand as a fine aggregate led to a reduction of $39 \%$ in the flexural strength and a reduction of $26 \%$ in the compressive strength. The reduction of strength can be caused by the development of secondary ettringite in the hardened concrete, which due to volume expansion generated internal tensions and weakened the concrete resulting in a reduction in mechanical properties. Therefore, the gradual reduction in compressive strength of samples can be explained by the formation of secondary ettringite in the hardened concrete, which due to volume expansion develops internal tensions within the material micro-structure.

Aslam, M., Shafigh, P., Jumaat, M. Z., \& Lachemi, M. (2015). Benefits of using blended waste coarse lightweight aggregates in structural lightweight aggregate concrete. Journal of Cleaner Production, 119, 108-117. https://doi.org/10.1016/j.jclepro.2016.01.071
De Brito, J., Ferreira, J., Pacheco, J., Soares, D., \& Guerreiro, M. (2016). Structural, material, mechanical and durability properties and behaviour of recycled aggregates concrete. Journal of Building Engineering, 6, 1-16. https://doi.org/10.1016/j. jobe.2016.02.003

\section{References}


Lee, S. H., Hong, K. N., Park, J. K., \& Ko, J. (2014). Influence of aggregate coated with modified sulfur on the properties of cement concrete. Materials, 7(6), 4739-4754. https://doi.org/10.3390/ma7064739

Li, L. J., Tu, G. R., Lan, C., \& Liu, F. (2015). Mechanical characterization of waste-rubber-modified recycled-aggregate concrete. Journal of Cleaner Production, 124, 325-338. https://doi.org/10.1016/j. jclepro.2016.03.003

Medina, C., Sánchez De Rojas, M. I., Thomas, C., Polanco, J. A., \& Frías, M. (2016). Durability of recycled concrete made with recycled ceramic sanitary ware aggregate. Inter-indicator relationships. Construction and Building Materials, 105, 480-486. https:// doi.org/10.1016/j.conbuildmat.2015.12.176

Mohamad Syamir Senin, Shahiron Shahidan, Alif Syazani Leman, N. I. R. R. H. (2016). Analysis of Physical Properties and Mineralogical of Pyrolysis Tires Rubber Ash Compared Natural Sand in
Concrete material. IOP Publishing. https://doi. org/10.1088/1757-899X/160/1/012053

Singh, S., Nagar, R., \& Agrawal, V. (2015). A review on Properties of Sustainable Concrete using granite dust as replacement for river sand. Journal of Cleaner Production, 126, 74-87. https://doi. org/10.1016/j.jclepro.2016.03.114

Thomas, C., Cimentada, A., Polanco, J. A., Setién, J., Méndez, D., \& Rico, J. (2013). Influence of recycled aggregates containing sulphur on properties of recycled aggregate mortar and concrete. Composites Part B: Engineering, 45(1), 474-485. https://doi. org/10.1016/j.compositesb.2012.05.019

Vaičiukynienè, Danutė; Bocullo, Vytautas; Kantautas, Aras, Bistrickaite, R. (2016). Properties of geopolymer concrete with sulphur slime aggregate. Chania: Technical University of Crete.

Vektaris B. Vilkas V. Betono tvarumas [Durability of conrete]. Kaunas: Technologija; 2006.

\section{About the authors}

\section{VYTAUTAS BOCULLO}

PhD Student

Kaunas University of Technology,

Faculty of Architecture and Civil Engineering, Department of Building Materials

\section{Main research} area

Alkali activated and geopolymer concrete

\section{Address}

Studentų st. 48 LT51367 Kaunas,

Lithuania

Tel.+37068248654

E-mail:

Vytautas.bocullo@ ktu.edu

\section{DANUTÉ VAIČIUKYNIENÉ}

Professor

Kaunas University

of Technology,

Faculty of

Architecture and

Civil Engineering,

Department of

Building Materials

Main research

area

Zeolites, alkali activated and geopolymer materials, reuse of industrial waste

\section{Address}

Studentu st. 48

LT51367 Kaunas,

Lithuania

Tel. +37065766815

E-mail:

Danute.

paliubinskaite@ktu.lt
ARAS

KANTAUTAS

Asocc. Professor

Kaunas University

of Technology,

Faculty of Chemical

Technology,

Department of

Silicate Technology

Main research area

Zeolites, alkali activated and geopolymer binding materials, by-products of chemical industry

\section{Address}

Radvilènų av. 19C

Kaunas, Lithuania Tel.+37068328595

E-mail: aras.kantautas@ ktu.lt
RUBEN PAUL BORG

Senior Lecturer

University of Malta

Main research area

Concrete, cement, Durability, building materials, waste and by-product recycling

\section{Address}

Department of Construction

\& Property Management, Faculty for the Built Environment, Built Environment Building, Room 213, University of Malta, Msida, MSD 2080, Malta

E-mail: ruben.p.borg@ um.edu.mt
GITANA ŠUKAITAITÉ

Asocc. Professor

Kaunas University of Technology,

Faculty of Architecture and Civil Engineering, Department of Architecture and Land Management

\section{Main research} area

Architecture, art criticism

\section{Address}

Faculty of Architecture and Civil Engineering, Department of Architecture and Land Management Tel. +37061121207 E-mail: gitana.sukaityte@ ktu.lt 